\title{
Visceral leishmaniasis in border areas: clustered distribution of phlebotomine sand flies in Clorinda, Argentina
}

\author{
Oscar D Salomón ${ }^{1 /+}$, María G Quintana ${ }^{2}$, Mario R Bruno ${ }^{3}$, Ricardo V Quiriconi ${ }^{3}$, Viviana Cabral ${ }^{3}$ \\ ${ }^{1}$ Centro Nacional de Diagnóstico e Investigación en Endemo-epidemias, Av. Paseo Colón 568, 1063 Buenos Aires, Argentina \\ ${ }^{2}$ Universidad Nacional de Tucumán, Tucumán, Argentina ${ }^{3}$ Ministerio de Desarollo Humano Formosa, Formosa, Argentina
}

Three years after the first report of Lutzomyia longipalpis in Clorinda, Argentina, a border city near Asunción, Paraguay, the city was surveyed again. Lu. longipalpis was found clustered in the same neighbourhoods in 2007 as in 2004, even though the scattered distribution of canine visceral leishmaniasis was more related to the traffic of dogs through the border.

Key words: visceral leishmaniasis - Lutzomyia longipalpis - Argentina

During the last few decades, visceral leishmaniasis (VL) has become a serious public health threat due to its geographical spread, association with HIV and resistance to therapeutic drugs. In South America, recent reports have shown the dispersion of Leishmania infantum chagasi to urban environments in the south with the dog (Canis familiaris) as its main reservoir and Lutzomyia longipalpis as its main vector (Gontijo \& Melo 2004, Lainson \& Rangel 2005).

In Argentina, 14 cases of human VL were reported from 1925-1989 in the cutaneous leishmaniasis endemic area. However, up to that time, the only record of $L u$. longipalpis was at the northeastern border and it was not associated with cases of VL (Salomón et al. 2001). Since the year 2000 , due to the L. i. chagasi-associated VL outbreaks that occurred in Mato Grosso do Sul (MS), Brazil and Paraguay (Cousiño 2006, Oliveira et al. 2006, Mestre \& Fontes 2007), close to the northern Argentinean border, vector surveillance has intensified. In December 2004, Lu. longipalpis was found in Clorinda, Argentina, $40 \mathrm{~km}$ from Asunción, Paraguay (Salomón \& Orellano 2005). During 2006, the first autochthonous focus of $L$. $i$. chagasi transmission associated with human and canine VL and Lu. longipalpis captures was reported in Posadas, Argentina (Salomón et al. 2008b). In October 2007, three years after the first report of $L u$. longipalpis in Clorinda, the city and surroundings were surveyed again to describe the current dispersion of vectors in this area, which experiences intense movement of humans and dogs to and from an active VL focus through the international border with Paraguay.

Clorinda (25 $17^{\circ} \mathrm{LS} 57^{\circ} 43^{\prime} \mathrm{LW}, 62$ masl), which has 47,000 inhabitants, is located at the northeastern border of the province of Formosa on the right bank of the Pilcomayo River $10 \mathrm{~m}$ away from its junction with the Para-

+ Corresponding author: odanielsalomon@gmail.com

Received 22 April 2009

Accepted 30 June 2009 guay River (Figure). Three pedestrian bridges and many eventual fords link Clorinda to Nananawa in Paraguay, which is $40 \mathrm{~km}$ from Asunción, Paraguay's capital city and $115 \mathrm{~km}$ away from the capital of the province of Formosa by highway. The Clorinda area belongs to the eastern Chaco Region (Cabrera 1976), which has a subtropical wet climate, Köeppen type A2Aw, mean temperature of $23^{\circ} \mathrm{C}\left(-2-43^{\circ} \mathrm{C}\right)$ and an average annual rainfall of 900-1000 $\mathrm{mm}$, with rain occurring throughout the whole year and the driest period running from June-August (Salomón et al. 2008a).

Phlebotominae sand flies were caught with minilight CDC traps operating overnight from 19:00-9:00 h from October 18-October 31, 2007. Clorinda-Puerto Pilcomayo was divided into $400 \mathrm{x} 400 \mathrm{~m}$ areas and at least one site was sampled in each area, with the "worst scenario" being the environment more prone to having sand flies (Figure). The traps were located in the shade $1.5 \mathrm{~m}$ above the ground during two consecutive nights. At each sampled site, the households were asked about dogs diagnosed with or having died from L. i. chagasi infections in the domicile. Additional captures were performed in Laguna Blanca and Laguna Naineck (Figure). The sand flies were kept dry until were macerated in lacto-phenol for identification following the key of Young and Duncan (1994) or as described by Andrade Filho et al. (2003) for Lutzomyia neivai (2003).

At 18 out of the 140 sampled sites, 106 sand flies belonging to five species were collected: Lu. longipalpis $(50.5 \%$ of the total sand flies), Lu. neivai $(43.9 \%)$, Lutzomyia cortelezzii (2.8\%), Lutzomyia migonei $(0.9 \%)$ and Brumptomyia guimaraesi (1.4\%) (Table). Lu. longipalpis was found in 10 areas of Clorinda and Puerto Pilcomayo where it represented $80.6 \%$ of the captured sand flies, with a male prevalence of $75.9 \%$. The vector density was low by site (1-4 phlebotomine sand flies/ trap), except in Puerto Pilcomayo in the locations called "kilometro 9" and "kilometro 10" (12-28 phlebotomine sand flies/trap) (Table).

In Clorinda, in spite of the wider distribution of canine VL, most of the sand flies captured were clustered in the northern peripheral area, other than one trap in the downtown area in a house with a chicken 


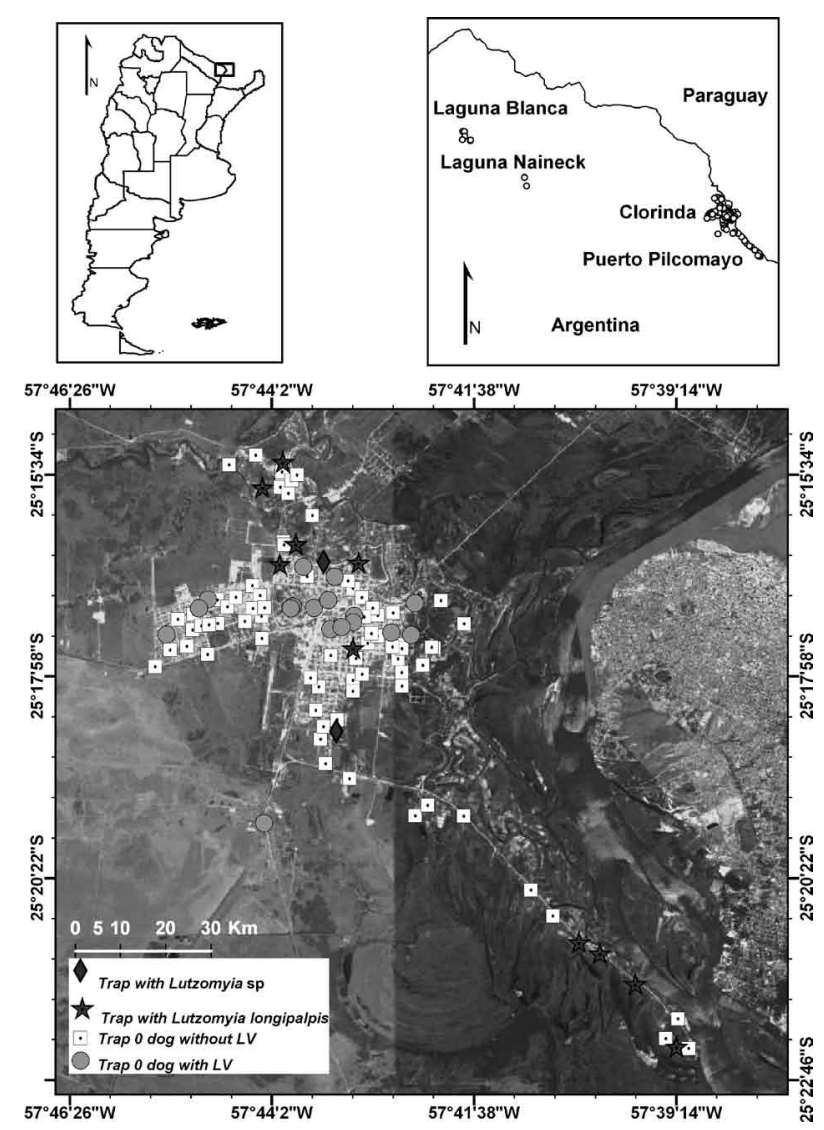

Phlebotomine capture site locations in Clorinda, Puerto Pilcomayo, Laguna Blanca and Laguna Naineck, Formosa, Argentina. Image was taken from Google Earth, version 4.0.2416 (beta) (http://earth.google. es). LV: visceral leishmaniasis.

house, while in Puerto Pilcomayo, Lu. longipalpis was found associated with chickens or pigs in houses on the border with Paraguay (Figure). On the other hand, in Laguna Blanca and Laguna Naineck, none of the phlebotomine sand flies trapped was Lu. longipalpis, even on a poultry farm where most of the specimens of $L u$. neivai were found (Table).

Lu. longipalpis spatial distribution in ClorindaPuerto Pilcomayo in October 2007 clustered in northern and southern outskirt areas, almost in the same sites described in December 2004 when the species was first reported in the province of Formosa (Salomón \& Orellano 2005), with no further spread to Laguna Blanca or Laguna Naineck. Similar to our results, high spatial heterogeneity of this vector has also been reported in the southern Brazilian focus of Campo Grande, where 90\% of the sand flies captured in the urban environment were Lu. longipalpis and $79.4 \%$ of the males were associated with peridomestic chicken houses (Araujo e Silva et al. 2007, Oliveira et al. 2008, Silva et al. 2008).

However, since the first report of Lu. longipalpis in Clorinda and in spite of its clustered distribution, at least 40 dogs with canine VL due to L. chagasi have been reported scattered all over the city. Although these cases could be attributed to intense dog movement across the border with Paraguay where the 2006 canine VL prevalence for Asunción was estimated to be $58 \%$ (Cousiño 2006), many of the infected dogs were born in Clorinda and never visited Paraguay, so local transmission cannot be discarded. Therefore, we can assume that the vectorial-related risk is spatially restricted during periods of low transmission (captures were performed after an exceptionally cold winter and before the rainfall season). On the other hand, during periods more suitable for the vectors, Lu longipalpis may colonise other neighbourhoods of the city, such as the yard with chickens and dogs in the downtown area that had phlebotomine sand flies. According to this hypothesis, Lu. longipalpis may have a metapopulational structure, already proposed for cutaneous leishmaniasis vectors in Argentina, with source populations and extinguishable sink populations (Salomón et al. 2004). If this is the case, a focused antivectorial intervention before the seasonal spread of $L u$. longipalpis might have a significant impact on preventing both canine VL and its eventual and predictable overspill to human VL. To evaluate this strategy, further investigations are required: a spatially intensive capture to delineate the "islands" of high sand fly abundance, time-longitudinal captures to describe the seasonal dynamics of the vectors and controlled trials to assess insecticide intervention effectiveness (Salomón 2008).

As in other border cities with similar scenarios of recent introduction of VL, there are some factors that could jeopardise this strategy in Clorinda: (i) the intense traffic of dogs across the border from an active focus of VL (strays, pets, trade of bred dogs); (ii) canine VL underreporting, as animals are more likely to be diagnosed in the areas closer to the focus where the veterinarians have more experience; (iii) movement of dogs inside the city (stray dogs, puppies) and (iv) massive human migration with dogs, as when the road and gas pipeline was built in MS (Correa Antonialli et al. 2007). The first two factors are related to border legislation or law enforcement, the third to responsible pet ownership and the last to health risk assessments of developmental projects.

The recommendations given here about insecticide intervention in vectorial "hot spots" or areas with $L u$. longipalpis were followed by the authorities. Although this procedure has not been evaluated, in November 2008, of the over 3,661 dogs surveyed in Clorinda, 111 $(3.03 \%)$ were rK39 positive and $90 \%$ of these animals were culled. Additionally, no human cases have been diagnosed or even suspected since 2004 despite clinical surveillance by the local hospital and primary health care agents. During the same period in the foci of MS and Asunción, the figures of canine and human VL rose, although specific environmental characteristics of Clorinda and the surroundings that restrain the vector dispersion cannot be ruled out as an explanation for the decreased incidence of VL.

In conclusion, Clorinda is still at high risk of becoming an intense focus of VL transmission and a source of dispersion to the south along the highly trafficked roads; however, after three years the vector has not colonised 


\section{TABLE}

Phlebotomine sampled with CDC trap in Clorinda, Puerto Pilcomayo, Laguna Blanca and Laguna Naineck, Formosa, Argentina, from October 18-31 2007 by site, sex and species (only sites with phlebotomine)

\begin{tabular}{|c|c|c|c|c|c|c|}
\hline Locality & $\begin{array}{c}\text { Coordenates } \\
(\mathrm{LS}, \mathrm{LW})\end{array}$ & $\begin{array}{l}\text { Lutzomyia } \\
\text { longipalpis }\end{array}$ & $\begin{array}{l}\text { Lutzomyia } \\
\text { neivai }\end{array}$ & $\begin{array}{l}\text { Lutzomyia } \\
\text { cortelezzii }\end{array}$ & $\begin{array}{l}\text { Lutzomyia } \\
\text { migonei }\end{array}$ & $\begin{array}{c}\text { Brumptomyia } \\
\text { guimaraesi }\end{array}$ \\
\hline Clorinda & $25^{\circ} 15^{\prime} 24.0 " 57^{\circ} 43^{\prime} 53.7^{\prime \prime}$ & & & & & $1 / 0$ \\
\hline Clorinda & $25^{\circ} 15^{\prime} 37.7^{\prime \prime} 57^{\circ} 43^{\prime} 49.0^{\prime \prime}$ & & & $0 / 1$ & & \\
\hline Clorinda & $25^{\circ} 15^{\prime} 42.4^{\prime \prime} 57^{\circ} 44^{\prime} 08.6^{\prime \prime}$ & $1 / 0$ & & & & \\
\hline Clorinda & $25^{\circ} 15^{\prime} 24.33^{\prime \prime} 57^{\circ} 43^{\prime} 54.0 "$ & $0 / 1$ & & & & \\
\hline Clorinda & $25^{\circ} 16^{\prime} 23.0^{\prime \prime} 57^{\circ} 43^{\prime} 44.9^{\prime \prime}$ & $1 / 2$ & $2 / 5$ & & & \\
\hline Clorinda & $25^{\circ} 16 ’ 36.00^{\prime} 57^{\circ} 43^{\prime} 25.1^{\prime \prime}$ & & $0 / 2$ & & & \\
\hline Clorinda & $25^{\circ} 18^{\prime} 36.9^{\prime \prime} 57^{\circ} 43^{\prime} 16.1^{\prime \prime}$ & & & $0 / 1$ & & \\
\hline Clorinda & $25^{\circ} 16^{\prime} 36.4^{\prime \prime} 57^{\circ} 43^{\prime} 00.2^{\prime \prime}$ & $1 / 0$ & & & & \\
\hline Clorinda & $25^{\circ} 16^{\prime} 37.3 " 57^{\circ} 43^{\prime} 56.3 ”$ & $4 / 0$ & & $0 / 1$ & & \\
\hline Clorinda & $25^{\circ} 17^{\prime} 37.2^{\prime \prime} 57^{\circ} 43^{\prime} 04.0^{\prime \prime}$ & $2 / 0$ & & & & \\
\hline Puerto Pilcomayo & $25^{\circ} 21^{\prime} 07.0^{\prime \prime} 57^{\circ} 40^{\prime} 23.1^{\prime \prime}$ & $9 / 3$ & & & & \\
\hline Puerto Pilcomayo & $25^{\circ} 21^{\prime} 15.1 " 57^{\circ} 40^{\prime} 08.5^{\prime \prime}$ & $1 / 0$ & & & & \\
\hline Puerto Pilcomayo & $25^{\circ} 21^{\prime} 36.9^{\prime \prime} 57^{\circ} 39^{\prime} 43.0 ”$ & $22 / 6$ & & & & \\
\hline Puerto Pilcomayo & $25^{\circ} 22^{\prime} 21.5^{\prime \prime} 57^{\circ} 39^{\prime} 13.8^{\prime \prime}$ & $0 / 1$ & & & & \\
\hline Laguna Blanca & 2508'01.7" 58¹4'19.1" & & $1 / 0$ & & & \\
\hline Laguna Blanca & $25^{\circ} 08^{\prime} 26.0 " 58^{\circ} 14^{\prime} 35.9 ”$ & & $2 / 27$ & & $1 / 0$ & \\
\hline Laguna Naineck & $25^{\circ} 12^{\prime} 58.2^{\prime \prime} 58^{\circ} 07^{\prime} 12.5^{\prime \prime}$ & & $0 / 8$ & & & $1 / 0$ \\
\hline
\end{tabular}

the closest villages, where the phlebotomine species are still the usual for the region (Salomón et al. 2008a). The VL canine prevalence is not a good space-time indicator of parasite circulation or transmission intensity in these early VL scenarios close to borders with active VL transmission. However, the spatially clustered distribution of vectors allows for possible anti-vectorial preventive interventions, together with regular surveillance measures of canine VL and human VL, vector dispersion monitoring and international sanitary law enforcement.

\section{ACKNOWLEDGEMENTS}

To Anibal Gómez, Angel Tijera (Formosa), Nelson Gutierrez (Clorinda), Vega (Laguna Blanca), Bertolou (Laguna Naineck) - Ministerio de Desarrollo Humano de la Provincia de Formosa - for their support, to Fundación Mundo Sano Clorinda, to Carlos Pino (Formosa), Ireneo Duisit, Eduardo Franco, Ana Gayato, Marta Fernández, Walter Núñez, Milán Martínez, Raquel Azula, Paulina Sosa Maldonado, Adela Ibañez, Maximo Cabral, Cármen Haedo, Luisa Jaimez (Clorinda) Hermosilla (Laguna Blanca) - Ministerio de Desarrollo Humano de la Provincia de Formosa - for their technical help in the field, and to Hilda Morel and Catalina Espinoza (Veterniary of Clorinda), Evangelina Aldama (Fundación Mundo Sano), Sara Jojot and Silvia Vallovera (animal protection society, Clorinda) and Cdte. Esquivel (Gendarmería Nacional).

\section{REFERENCES}

Andrade Filho JD, Galati EA, Falcão AL 2003. Redescription of Nyssomyia intermedia (Lutz \& Neiva, 1912) and Nyssomyia neivai (Pinto, 1926) (Diptera: Psychodidae). Mem Inst Oswaldo Cruz 98: 1059-1065.
Araujo e Silva E, Andreotti R, Honer MR 2007. Comportamento de Lutzomyia longipalpis, vetor principal da leishmaniose visceral americana, em Campo Grande, Estado do Mato Grosso do Sul. Rev Soc Bras Med Trop 40: 420-425.

Cabrera AL 1976. Regiones fitogeográficas Argentinas. In AL Cabrera, Enciclopedia Argentina de Agricultura y Jardinería, Tomo II, Editorial ACME SACI, Buenos Aires, p. 1-85.

Correa Antonialli SA, Torres TG, Paranhos Filho AC, Tolezano JE 2007. Spatial analysis of American visceral leishmaniasis in Mato Grosso do Sul state, Central Brazil. J Infect 54: 509-514.

Cousiño B 2006. Vigilancia y control de la leishmaniasis en Paraguay. In Panaftosa, Informe final de la reunión de expertos OPS/OMS sobre Leishmaniasis Visceral en las Américas, Panaftosa, Rio de Janeiro, p. 34-36.

Gontijo CM, Melo MN 2004. Leishmaniose visceral no Brasil: quadro atual, desafios e perspectivas. Rev Bras Epidemiol 7: 338-349.

Lainson R, Rangel EF 2005. Lutzomyia longipalpis and the eco-epidemiology of American visceral leishmaniasis, with particular reference to Brazil - A review. Mem Inst Oswaldo Cruz 100: 811-827.

Mestre GLC, Fontes CJF 2007. A expansão da epidemia da leishmaniose visceral no Estado de Mato Grosso, 1998-2005. Rev Soc Bras Med Trop 40: 42-48.

Oliveira AG, Galati EA, Fernandes CE, Dorval ME, Brazil RP 2008. Seasonal variation of Lutzomyia longipalpis (Lutz \& Neiva, 1912) (Diptera: Psychodidae: Phlebotominae) in endemic area of visceral leishmaniasis, Campo Grande, state of Mato Grosso do Sul, Brazil. Acta Tropica 105: 55-61.

Oliveira AL, Paniago AM, Dorval ME, Oshiro ET, Leal CR, Sanches M, Cunha RV, Bóia MN 2006. Foco emergente de leishmaniose visceral em Mato Grosso do Sul. Rev Soc Bras Med Trop 39: 446-450. 
Salomón OD 2008. Research on vectors of leishmaniasis: trends and questions. In PAHO/WHO-SOPERJ, Update of American trypanosomiasis and leishmaniasis control and research: $\mathrm{Fi}$ nal Report, Rio de Janeiro, Brazil, 6-7 November 2007, PAHO/ $\mathrm{HDM} / \mathrm{CD} / 512-2008$, Pan American Health Organization, Rio de Janeiro, p. 126-143.

Salomón OD, Orellano PW 2005. Lutzomyia longipalpis in Clorinda, Formosa province, an area of potential visceral leishmaniasis transmission in Argentina. Mem Inst Oswaldo Cruz 100: $475-476$.

Salomon OD, Rosa JR, Stein M, Quintana MG, Visintín A, Spinelli GR, Bogado de Pascual M, Molinari ML, Fernández MS, Morán ML, Valdez D, Bruno MR 2008a. Phlebotominae fauna in the Chaco Region and cutaneous leishmaniasis transmission patterns in Argentina. Mem Inst Oswaldo Cruz 103: 578-584.

Salomón OD, Rossi G, Sosa Estani S, Spinelli G 2001. Presencia de
Lutzomyia longipalpis y situación de la leishmaniosis visceral en Argentina. Medicina (Buenos Aires) 61: 174 -178.

Salomón OD, Sinagra A, Nevot MC, Barberian G, Paulin P, Estevez JO, Riarte A, Estevez J 2008b. First visceral leishmaniasis focus in Argentina. Mem Inst Oswaldo Cruz 103: 109-111.

Salomon OD, Wilson ML, Munstermann LE, Travi BL 2004. Spatial and temporal patterns of phlebotominae sand flies (Diptera: Psychodidae) in a cutaneous leishmaniaisis focus in Northern Argentina. J Med Entomol 41: 33-39.

Silva EA, Andreotti R, Dias ES, Barros JC, Brazuna JC 2008. Detection of Leishmania DNA in phlebotomines captured in Campo Grande, Mato Grosso do Sul, Brazil. Exp Parasitol 119: 343-348.

Young DG, Duncan MA 1994. Guide to the identification and geographic distribution of Lutzomyia sand flies in Mexico, the West Indies, Central and South America (Diptera: Psychodidae). Mem Am Entomol Inst 54: 1-881. 